\title{
RANCANG BANGUN SOLAR TRACKER OTOMATIS PADA PENGISIAN ENERGI PANEL SURYA BEBASIS INTERNET OF THINGS
}

\author{
Alfin Syarifuddin Syahab ${ }^{*}$, Hanif Cahyo Romadhon ${ }^{1}$, M. Luqman Hakim ${ }^{2}$ \\ ${ }^{1}$ Prodi Instrumentasi, Sekolah Tinggi Meteorologi Klimatologi dan Geofisika, Tangerang Selatan \\ ${ }^{2}$ Badan Meteorologi Klimatologi dan Geofisika, Jakarta \\ ${ }^{*}$ E-mail: alfinsyarifuddin@gmail.com
}

\begin{abstract}
ABSTRAK
Indonesia merupakan negara tropis yang mendapatkan pencahayaan sinar matahari optimum di permukaan bumi. Sementara kebutuhan energi listrik meningkat dikarenakan pertumbuhan penduduk dan perkembangan teknologi. Hal ini menyebabkan adanya kebutuhan suatu energi alternatif. Salah satu inovasi untuk mendapatkan energi listrik adalah dengan cara memanfaatkan cahaya matahari menggunakan panel surya. Panel surya adalah alat yang mampu mengubah energi panas dari cahaya matahari menjadi energi listrik. Panel surya akan menerima daya sebesar intensitas cahaya matahari yang diterimanya dari pancaran cahaya matahari. Namun banyak dipasang secara tetap, sehingga daya yang terserap oleh panel surya menjadi tidak maksimum akibat penyerapannya yang tidak optimal. Penelitian ini bertujuan untuk merancang suatu alat yang mampu menyerap pancaran cahaya matahari secara optimal dengan menggunakan sistem pelacak otomatis berbasis mikrokontroler 2560. Sistem pelacak energi surya tersebut mampu menyerap energi listrik rata-rata sesaat 9.933 Watt, sedangkan energi rata-rata sesaat yang dihasilkan sistem panel surya statis adalah 0.8 Watt. Hasil monitoring tersebut dapat dilihat menggunakan sistem komunikasi berbasis internet secara realtime yang ditampilkan pada display web thingspeak.com dan aplikasi android virtuino.
\end{abstract}

Kata Kunci: Sinar Matahari, energi listrik, solar tracker, mikrokontroler, internet.

\begin{abstract}
Indonesia is a tropical country that receives optimum level of sunlight on the surface of earth. In other hand, the needs of electrical energy increase because of population growth and technological development. it causes needs of a alternative energy. One of inovation to get electrical energy is from sunlight using solar panels. Solar panel is instrument that can convert heat energy from sun to electrical energy. Solar panel will absorb power as same as intensity of sunlight that is received. But there are still many static solar panels. So the power is not optimum when using static solar panels because of low receiving. This experiment has purpose to create instrument that is capable to absorb emission of sunlight optimally using system of solar tracker based on microcontroller 2560. This system of solar tracker is capable to receive momentary average of electrical energy is 9.333 Watts while the momentary average of electrical energy in static solar panel is 0.8 Watts. These results of monitoring are sent to user using communication system based on internet with realtime data. The data can be displayed in website thingspeak.com and application android virtuino.
\end{abstract}

Keywords: Sun light, electrical energy, solar tracker, microcontroller, internet.

\section{PENDAHULUAN}

Di era teknologi seperti saat ini, kebutuhan masyarakat Indonesia terhadap energi listrik sangatlah tinggi. Hal ini dikarenakan adanya pertambahan jumlah penduduk dan kemajuan teknologi. Hampir semua aktivitas masyarakat Indonesia menggunakan energi listrik. Contohnya aktivitas rumah tangga dan industri. Salah satu upaya untuk mencari energi alternatif adalah dengan menggunakan energi matahari. Energi matahari adalah energi yang dapat diperbaharui dan dapat diubah menjadi energi listrik menggunakan panel surya.

Panel surya merupakan kumpulan sel surya yang berfungsi merubah energi surya menjadi energi listrik. Pemanfaatan energi surya sebagai sumber energi listrik dapat 
dihasilkan menggunakan panel fotovoltaik atau pemusatan sinar surya. Oleh karena itu, untuk mendapatkan efisiensi maksimum dari cahaya matahari, maka panel surya harus selalu dalam posisi menghadap arah cahaya matahari. Berdasarkan rotasi bumi, maka posisi matahari tidak selalu sama setiap saat. Pada waktu tertentu, matahari berada di belahan bumi utara, terkadang pula berada di belahan bumi selatan ataupun di garis khatulistiwa. Akibatnya, panel surya tidak mampu menyerap energi matahari secara maksimal karena perubahan posisi matahari di setiap waktunya. Untuk mendapatkan efisiensi maksimum, maka panel surya harus mengikuti pergerakan matahari. Posisi panel surya terhadap matahari harus dikendalikan secara otomatis dengan suatu sistem penggerak panel surya menggunakan teknologi sistem instrumentasi mikrokontroler.

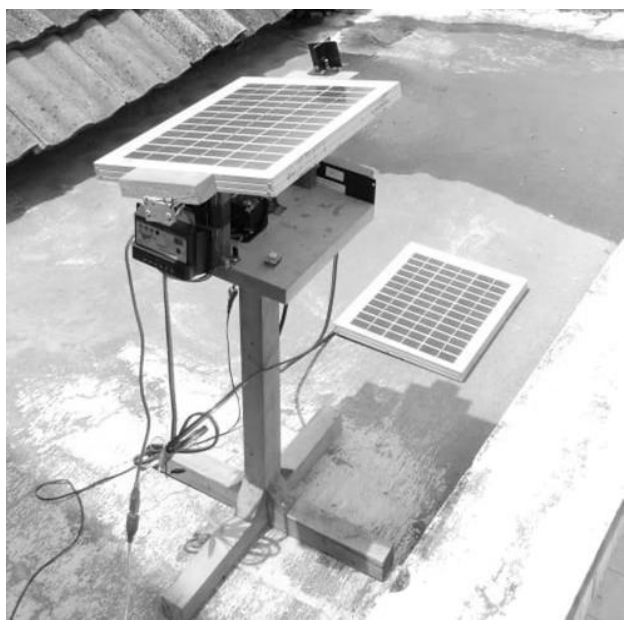

Gambar 1. Panel Surya Pelacak Matahari

Pada penelitian ini akan dibahas mengenai analisis perbandingan efisiensi panel surya yang dilengkapi dengan sistem pelacak matahari dengan panel surya yang dipasang secara tetap. Analisis dilakukan untuk menentukan efisiensi hasil yang diperoleh dari kedua sistem panel surya tersebut. Perbandingan hasil antara keduanya diharapkan dapat memberkani rekomendasi dalam pengambilan keputusan untuk pemanfaatan panel surya yang lebih baik.

\section{METODE}

Pengujian peralatan dilakukan di atas atap rumah pada kondisi matahari bersinar penuh sepanjang hari pada hari Kamis, 24 Januari 2019 dari pukul 06.00 - 09.30 UTC (13.00 $16.30 \mathrm{WIB}$ ) pada interval waktu pengambilan data setiap menit 15 menit untuk mendapatkan data arus, tegangan dan daya listrik. Metode yang digunakan dalam penelitian ini adalah uji eksperimental. Eksperimen dilakukan terhadap sistem mekanik dinamik kerangka dari kedudukan panel surya. Sehingga metode pengontrolan panel surya mencapai kondisi yang diinginkan yaitu permukaan panel surya tegak lurus terhadap sinar matahari datang. Adapun metode penelitian yang digunakan dalam membuat tulisan ini diantaranya:

\subsection{Membuat Blok Diagram Kerja Alat}

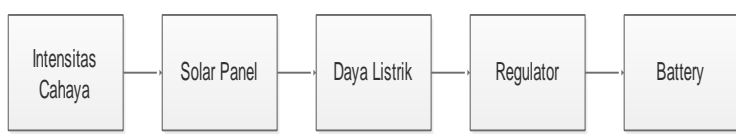

Gambar 2. Blok diagram solar panel

Perancangan sistem pelacak matahari menggunakan prinsip kerja sensor cahaya LDR. Sensor akan mengirimkan sinyal ke mikrokontroler kemudian menggerakan motor stepper untuk memutar posisi panel surya. Energi surya yang diperoleh kemudian disimpan ke baterai untuk disimpan. Baterai menjadi perangkat yang dapat mengubah energi kimia langsung menjadi energi listrik.

\subsection{Membuat Blok Diagram Komponen}

Komponen utama yang digunakan untuk pembuatan alat solar tracker otomatis adalah sensor LDR, mikrokontroler berupa Arduino Uno dan Mega, motor stepper, regulator, dan panel surya. Baterai aki digunakan untuk menyimpan energi listrik yang dihasilkan panel surya dan juga sumber energi untuk peralatan. 


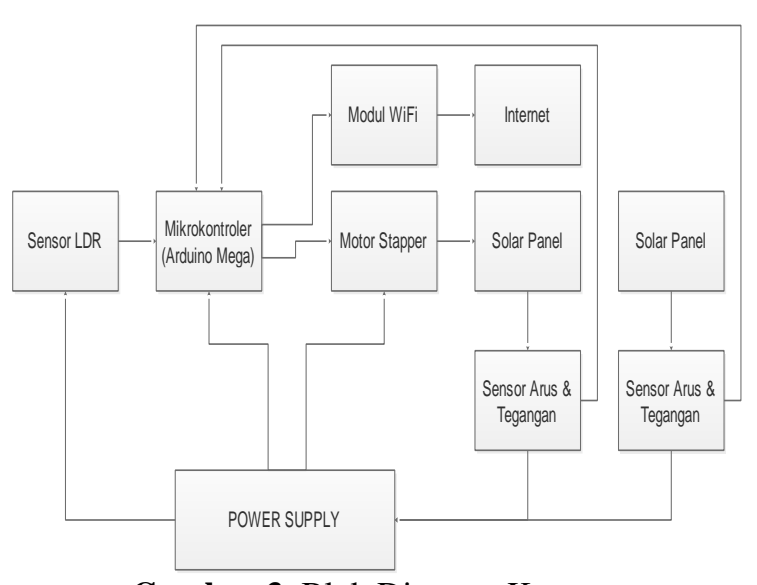

Gambar 3. Blok Diagram Komponen

\subsection{Membuat Blok Diagram Sistem Komunikasi}

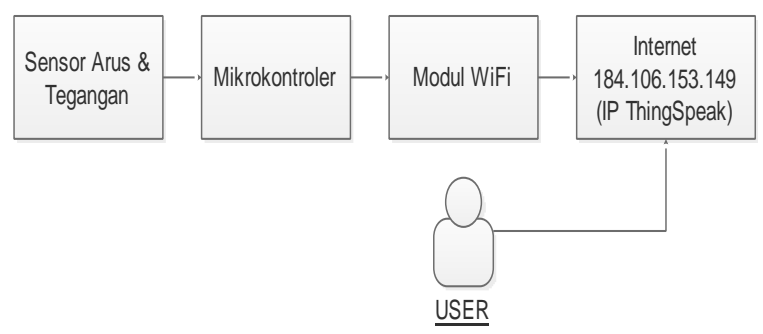

Gambar 4. Blok Diagram Sistem Komunikasi

Nilai energi listrik yang disimpan di baterai aki dapat dilihat secara real-time berbasis internet menggunakan website thingspeak.com dan aplikasi android virtuino yang kedua platform tersebut menyediakan GUI (Graphical User Interface) yaitu jenis antarmuka pengguna yang menggunakan interaksi peranti elektronik secara grafis (bukan perintah teks) antara pengguna dan komputer.

\subsection{Membuat Flowchart Alur Kerja Alat}

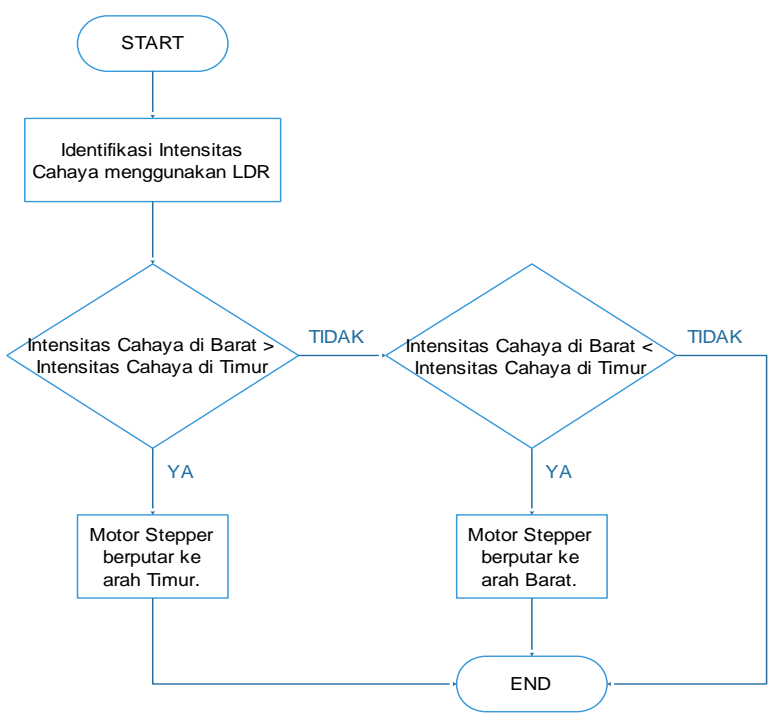

Gambar 5. Diagram Alir Kerja

Sistem kerja alat ini menggunakan logika pemrograman bahasa $\mathrm{C}$ dengan software Arduino IDE. Dalam Arduino IDE berisi sejumlah perintah yang mengatur arah putar motor stepper dengan pengaruh instensitas cahaya. Identifikasi intensitas cahaya dibantu oleh sensor LDR yang dikonversikan menjadi nilai resistansi. Dengan aturan peletakan poros sistem pelacak matahari menghadap utara-selatan, jika intensitas cahaya di sebelah barat panel surya lebih besar dari pada instensitas cahaya di sebelah timur maka motor stepper berputar ke arah timur. Sedangkan jika intensitas cahaya di sebelah timur panel surya lebih besar dari pada instensitas cahaya di sebelah barat maka motor stepper berputar ke arah barat.

\subsection{Metode Pengujian Alat}

Metode pengujian dilakukan dengan memasang sistem pelacak matahari dan panel surya tetap di tempat terbuka pada posisi sama. Kedua panel surya tersebut dikoneksikan pada regulator yang memberi jalan arus dan tegangan menuju ke aki baterai dan beban (alat elektronik yang digunakan). Komponen modul Wi-Fi pada mikrokontroler merupakan akses komunikasi data yang terkoneksi internet. Alat tersebut akan mengirimkan data setiap menit dalam nilai arus dan tegangan sesaat yang disajikan pada tabel dan grafik. 


\subsection{Cara Pembuatan Alat}

a. Merancang dudukan panel surya pelacak matahari dan tempat memasang komponen. Sistem pelacak matahari menggunakan satu sumbu horizontal.

b. Merangkai komponen-komponen alat. Proses ini dapat dilakukan percobaan pada projectboard kemudian dipasang pada PCB menggunakan solder.

c. Membuat program pada Arduino IDE. Program Arduino Mega untuk koneksi internet, sensor tegangan, dan sensor arus. Program Arduino Uno untuk sensor cahaya LDR dan motor stepper pada panel surya pelacak.

d. Membuat interface sebagai tampilan website pada ThingSpeak dan aplikasi virtuino pada Android.

\subsection{Metode Memperoleh Data}

Alat dioperasikan di ruang terbuka dalam waktu satu hari. Ketika alat sudah terkoneksi dengan Wi-Fi. Nilai arus dan tegangan yang didapatkan panel surya akan dikirimkan kepada user melalui akses komunikasi internet. Sistem komunikasi mengirimkan data setiap satu menit secara realtime. Data diterima berupa grafik fungsi nilai tegangan, arus, dan daya terhadap waktu. Data dapat diunduh dalam format excel. Dari format data tersebut dapat menjadi bahan analisis lebih lanjut.

\subsubsection{Analisis Data}

Data yang diperoleh panel surya pelacak matahari adalah data berkala setiap satu menit. Pada penelitian ini kami sederhanakan data yang akan dianalisis kurang lebih setiap 15 menit. Untuk memudahkan menganalisis data, maka dibuat tabel untuk parameterparameter pengukuran alat antara lain, arus, tegangan, dan daya pada panel surya pelacak dan tetap dan nilai yang dikeluarkan pada setiap waktu tertentu. Dari tabel tersebut dapat dilakukan analisis dengan cara melihat selisih antara arus, tegangan, dan daya pada panel surya pelacak dan panel surya tetap. Dari tabel yang dibuat dapat dikembangkan menjadi grafik fungsi arus, tegangan, dan daya terhadap waktu setiap 15 menit.

\section{HASIL DAN PEMBAHASAN}

3.1. Perancangan Alat

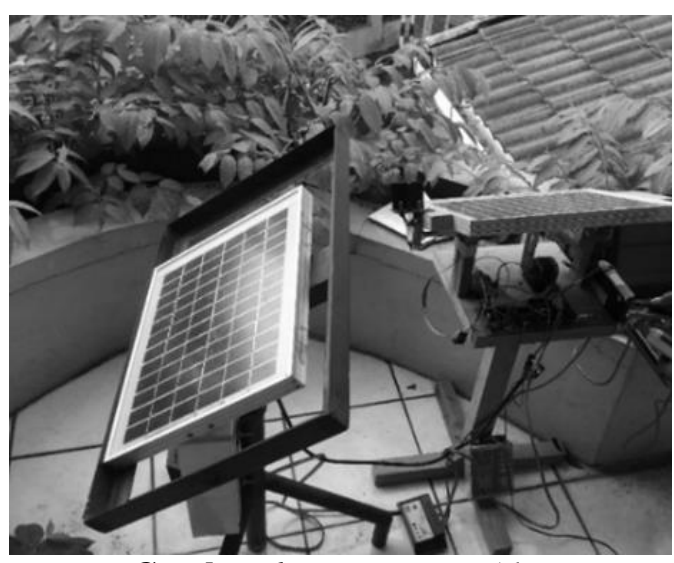

Gambar 6. Perancangan Alat

Alat dipasang di lapangan kemudian data nilai energi listrik yang diperoleh dapat diakses di rumah atau kantor. Data tersebut dipantau secara realtime dan dapat diketahui alat dalam kondisi normal atau mengalami kerusakan tanpa harus mengecek ke tempat alat dipasang. Panel surya sistem pelacak matahari otomatis ini dapat optimal menyimpan energi listrik lebih banyak dari panel surya tetap. Alat ini memiliki kemampuan mengikuti arah gerak matahari dengan single axis oleh motor penggerak yang terintegrasi dengan sensor cahaya matahari. Beberapa sistem pelacak energi surya secara otomatis dengan menggunakan mikrokontroler, sensor LDR dan motor stepper telah dibuat, baik dengan satu sumbu maupun dengan dua sumbu pergerakan terhadap matahari. 


\subsection{Pembuatan Dudukan Komponen}

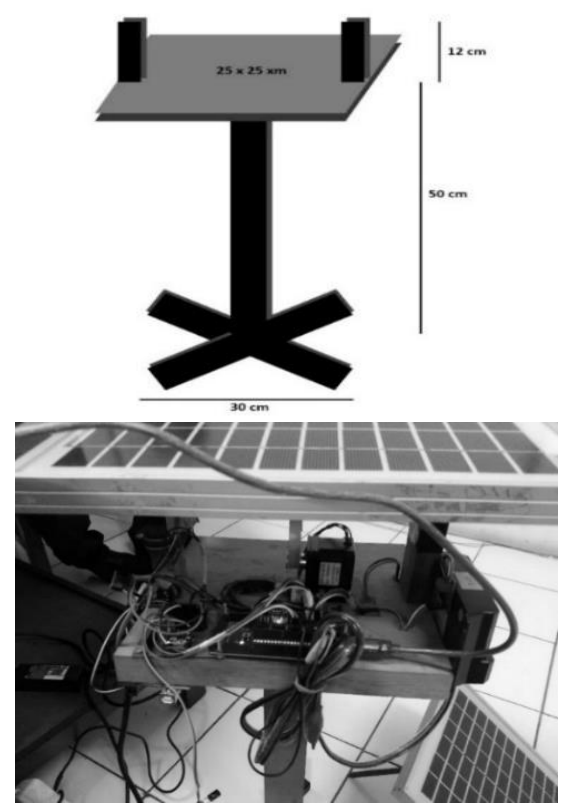

Gambar 7. Dudukan Komponen Alat

Dudukan panel surya dibuat dari kayu dengan ukuran tinggi $50 \mathrm{~cm}$ dan ukuran panjang sisi dudukan $25 \times 25 \mathrm{~cm}$. Dudukan ini dibuat sekuat mungkin menggunakan kayu karena lebih ekonomis dari pada bahan besi atau alumunium. Pada dudukan komponen dapat diberikan kotak tambahan untuk tempat komponen-komponen elektronika antara lain; arduino, modul Wi$\mathrm{Fi}$, sensor arus, sensor tegangan, dll untuk melindungi dari kondisi cuaca ketika panas dan hujan.

\subsection{Perancangan Komponen-Komponen}

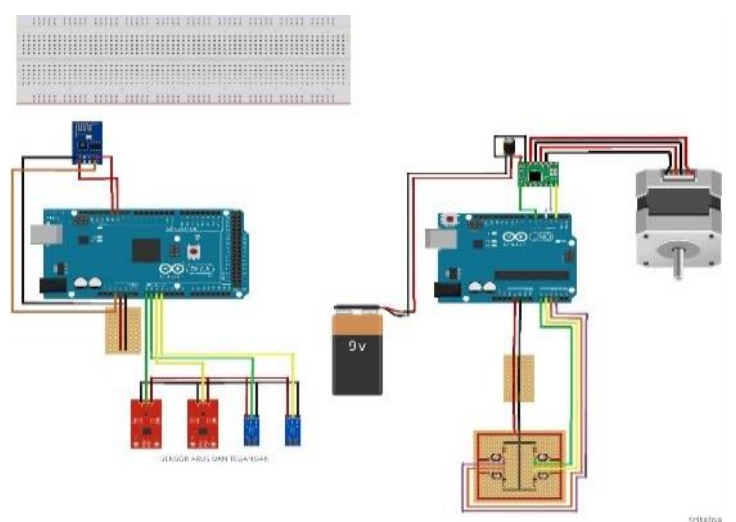

Gambar 8. Rangkaian Sistem dibuat dengan Software Fritzing

Panel surya pelacak matahari merupakan suatu sistem instrumentasi terdiri dari beberapa komponen yang saling terhubung dan memiliki cara kerja dan fungsi masing- masing. Maka perlu desain rangkaian sistem tersebut. Salah satu perangkat yang membantu dalam membuat gambar susunan komponen adalah fritzing. Fritzing memberikan fasilitas pengguna untuk melakukan perancangan sistem di breadboard. ${ }^{8}$ Dalam fritzing dapat ditemukan komponen elektronika dan sistem pengkabelan untuk menghubungkan antar dua komponen atau lebih sehingga menjadi skema komponen yang saling terkoneksi.

Penjelasan alur kerja pada rangkaian di atas terbagi menjadi dua kinerja berbeda. Di sebeleh kiri terdapat Arduino Mega terkoneksi dengan modul ESP, sensor tegangan 1, sensor tegangan 2, sensor arus 1 , sensor arus 2, dan pin header $\mathrm{V}+$ dan GND. Pada skema ini memiliki fungsi dalam monitoring energi listrik yang diterima oleh panel surya pelacak matahari dan panel surya tetap kemudian mengirimkan data tersebut ke perangkat yang dituju dengan akses komunikasi internet. Di sebelah kanan terdapat Arduino Uno terkoneksi dengan sensor cahaya LDR, driver, baterai, dan motor DC. Skema ini memiliki kinerja cahaya matahari mengenai LDR kemudian LDR memberikan input pada mikrokontroler Arduino Uno yang diteruskan ke motor DC untuk menggerakkan solar cell mengarah tegak lurus terhadap arah datangnya sinar matahari kemudian cahaya dikonversikan menjadi energi listrik kemudian energi disimpan ke baterai.

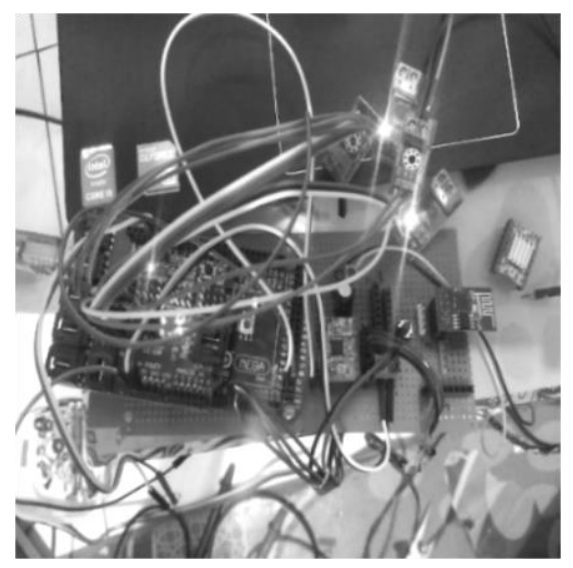

Gambar 9. Rangkaian Sistem pada Papan PCB 


\subsection{Pengujian Posisi Panel Surya Pelacak}

Pengujian peralatan sistem pelacak matahari otomatis dilakukan dengan memberikan cahaya ke sejumlah sensor cahaya untuk menguji respon sensor dalam menggerakkan motor. Pengujian dilakukan pada ruangan terbuka. Intensitas cahaya matahari terbesar diperoleh salah satu sensor dikirim ke mikrokontroler. Mikrokontroler memberi perintah ke motor stepper untuk menggerakkan panel surya ke posisi tegak lurus dengan matahari. Energi listrik yang diserap panel surya akan diatur oleh solar controller untuk disimpan pada baterai aki atau digunakan pada perangkat elektronik. Solar controller diperlukan sebagaian besar sistem panel surya yang menggunakan baterai untuk melindungi pengisian daya baterai yang berlebihan dan pemakaian berlebih. ${ }^{9}$

\subsection{Hasil Pengujian Alat Keseluruhan}

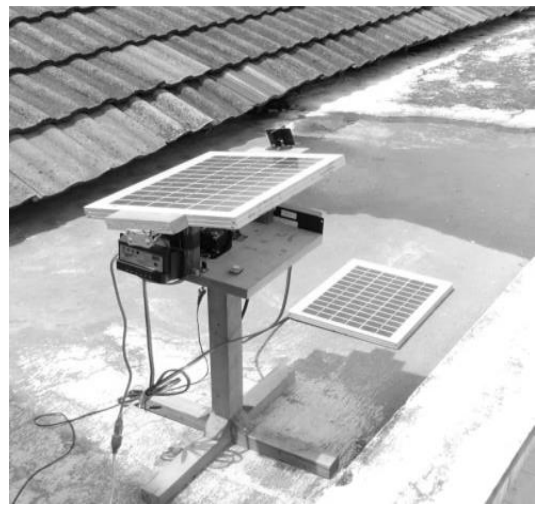

Gambar 10. Pengujian Panel Surya Pelacak dan Tetap

Pengujian peralatan dilakukan di atas atap rumah pada kondisi matahari bersinar penuh sepanjang hari. Data yang diperoleh adalah arus, tegangan dan daya listrik pada hari Kamis, 24 Januari 2019 dari pukul 06.00 09.30 UTC (13.00 - 16.30 WIB) pada interval waktu pengambilan data setiap menit 15 menit.

\subsection{Hasil Pengukuran dan Analisis}

Perbandingan energi anatara kedua panel surya tersebut disajikan dalam bentuk tabel dan gambar grafik. Hasil monitoring kedua panel surya secara realtime dapat dilihat melalui website thingspeak.com dan aplikasi android virtuino.

Tabel 1. Hasil Pengukuran Tegangan Panel Surya

\begin{tabular}{lll}
\hline WAKTU & TEGANGAN & TEGANGAN \\
(UTC) & PANEL 1 $(\mathrm{V})$ & PANEL 2 (V) \\
\hline $06: 00: 39$ & 15.62 & 20.92 \\
06:12:53 & 15.93 & 21.77 \\
06:31:06 & 15.13 & 20.87 \\
06:44:58 & 15.44 & 21.04 \\
07:00:20 & 15.32 & 21.58 \\
07:14:49 & 16.18 & 22.21 \\
07:31:11 & 15.54 & 21.55 \\
07:45:18 & 15.81 & 22.85 \\
08:01:38 & 14.96 & 20.63 \\
08:16:55 & 8.65 & 6.67 \\
08:30:32 & 14.69 & 20.16 \\
08:44:27 & 14.03 & 20.23 \\
09:02:18 & 14.15 & 20.14 \\
09:15:28 & 13.78 & 19.35 \\
09:32:10 & 13.76 & 18.57 \\
\hline Rata-rata & 14.59933333 & 19.90266667 \\
\hline
\end{tabular}

Dari Tabel 1 diperoleh data tegangan pada pengukuran panel surya pelacak matahari dan panel surya tetap. Hasil pengukuran rata-rata tegangan panel 1 atau panel surya tetap adalah 14.59933333 volt dan rata-rata tegangan panel 2 atau panel surya pelacak matahari adalah 19.90266667 volt. Data pengukuran diambil pada waktu 06.00.39 UTC - 09.32.10 UTC dengan interval setiap 15 menit.

Tabel 2. Hasil Pengukuran Arus Panel Surya

\begin{tabular}{lll}
\hline $\begin{array}{l}\text { WAKTU } \\
\text { (UTC) }\end{array}$ & $\begin{array}{l}\text { ARUS PANEL } 1 \\
\text { (A) }\end{array}$ & $\begin{array}{l}\text { ARUS PANEL } 2 \\
\text { (A) }\end{array}$ \\
\hline $06: 00: 39$ & -0.15 & 0.52 \\
$06: 12: 53$ & 0 & 0.52 \\
$06: 31: 06$ & 0.07 & 0.67 \\
$06: 44: 58$ & 0 & 0.59 \\
$07: 00: 20$ & 0.15 & 0.59 \\
$07: 14: 49$ & 0.07 & 0.44 \\
$07: 31: 11$ & 0 & 0.52 \\
$07: 45: 18$ & 0.07 & 0.52 \\
$08: 01: 38$ & 0 & 0.52 \\
$08: 16: 55$ & -0.07 & 0.67 \\
$08: 30: 32$ & 0.07 & 0.44 \\
$08: 44: 27$ & -0.15 & 0.52 \\
$09: 02: 18$ & 0 & 0.59 \\
$09: 15: 28$ & -0.07 & 0.44 \\
$09: 32: 10$ & -0.07 & 0.52 \\
\hline Rata-rata & 0.005333333 & 0.538 \\
\hline
\end{tabular}

Dari Tabel 2 diperoleh data arus pada pengukuran panel surya pelacak matahari dan 
panel surya tetap. Hasil pengukuran rata-rata arus panel 1 atau panel surya tetap adalah 0.005333333 ampere dan rata-rata arus panel 2 atau panel surya pelacak matahari adalah 0.538 ampere. Data pengukuran diambil pada waktu 06.00.39 UTC - 09.32.10 UTC dengan interval setiap 15 menit.

Tabel 3. Hasil Pengukuran Daya Panel Surya

\begin{tabular}{|c|c|c|}
\hline $\begin{array}{l}\text { WAKTU } \\
\text { (UTC) }\end{array}$ & $\begin{array}{l}\text { DAYA PANEL } 1 \\
\text { (W) }\end{array}$ & $\begin{array}{c}\text { DAYA PANEL } 2 \\
\text { (W) }\end{array}$ \\
\hline 06:00:39 & 2 & 10 \\
\hline $06: 12: 53$ & 0 & 11 \\
\hline 06:31:06 & 1 & 13 \\
\hline 06:44:58 & 0 & 12 \\
\hline 07:00:20 & 2 & 12 \\
\hline 07:14:49 & 1 & 9 \\
\hline 07:31:11 & 0 & 11 \\
\hline 07:45:18 & 1 & 11 \\
\hline 08:01:38 & 0 & 10 \\
\hline 08:16:55 & 0 & 4 \\
\hline 08:30:32 & 1 & 8 \\
\hline 08:44:27 & 2 & 10 \\
\hline 09:02:18 & 0 & 11 \\
\hline 09:15:28 & 1 & 8 \\
\hline 09:32:10 & 1 & 9 \\
\hline Rata-rata & 0.8 & 9.933333333 \\
\hline
\end{tabular}

Dari Tabel 3 diperoleh data daya pada pengukuran panel surya pelacak matahari dan panel surya tetap. Hasil pengukuran rata-rata daya panel 1 atau panel surya tetap adalah 0.8 watt dan rata-rata daya panel 2 atau panel surya pelacak matahari adalah 9.933333333 watt. Data pengukuran diambil pada waktu 06.00.39 UTC - 09.32.10 UTC dengan interval setiap 15 menit.

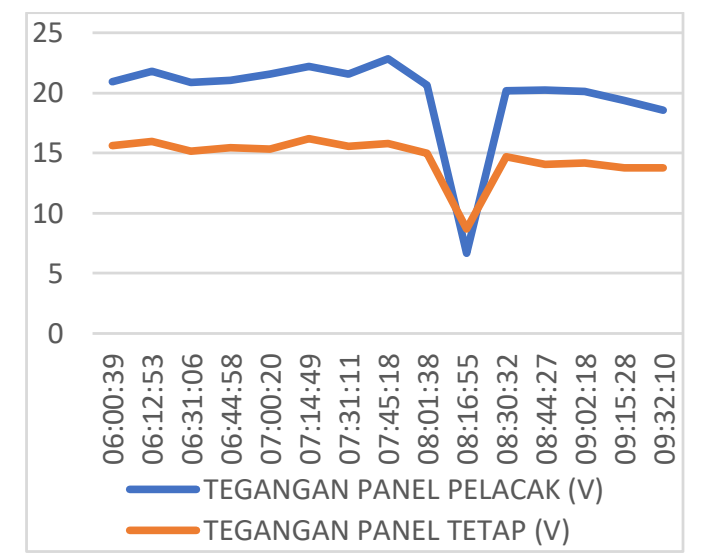

(A)

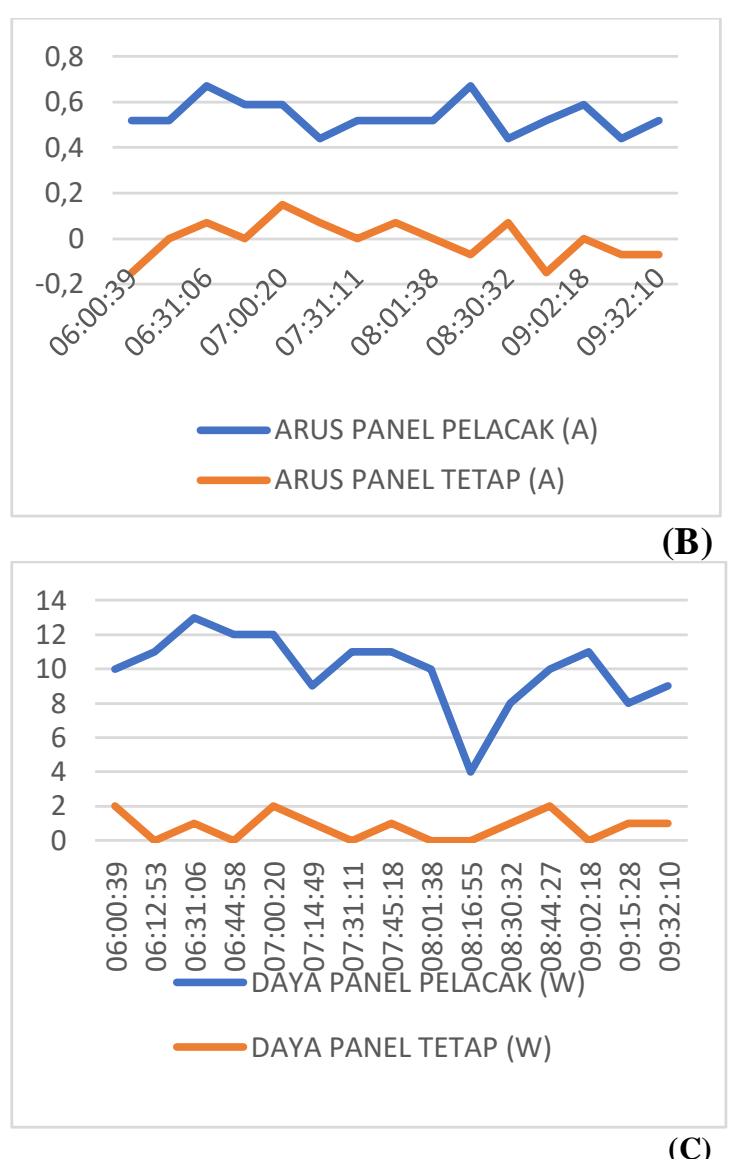

Gambar 11. Hasil Pengukuran Panel Surya (a)

Nilai Tegangan (b), Nilai Arus, dan (c) Nilai Daya.

Nilai tegangan yang terukur menggunakan satuan Volt dimana Panel 1 merupakan panel surya dipasang tetap dan Panel 2 merupakan panel surya yang dilengkapi dengan sistem pelacak matahari. Perbandingan nilai tegangan antara kedua sistem panel surya ditunjukkan oleh Gambar 11 (a). Gambar 11 (a) menunjukkan perbandingan nilai tegangan yang terukur antara panel surya tetap dan panel surya pelacak matahari pada 24 Januari 2019 dari pukul 06.00 - 09.30 UTC (13.00 - 16.30 WIB) lokasi di atap rumah. Dari gambar grafik tersebut dapat dilihat bahwa nilai tegangan yang dihasilkan panel surya pelacak matahari mengalami kenaikan rata-rata sebesar 5.303 Volt dibandingkan dengan nilai tegangan yang dihasilkan panel surya tetap.

Nilai arus yang terukur menggunakan satuan Ampere dimana Panel 1 merupakan panel surya tetap dan Panel 2 merupakan panel surya dengan sistem pelacak matahari. Perbandingan nilai arus antara kedua sistem 
panel surya ditunjukkan pada Gambar 11 (b). Gambar 11 (b) menunjukkan perbandingan nilai arus terukur antara panel surya tetap dan panel surya pelacak matahari pada 24 Januari 2019 dari pukul 06.00 - 09.30 UTC (13.00 16.30 WIB) lokasi di atap rumah. Dari gambar grafik tersebut dapat dilihat bahwa nilai arus yang dihasilkan oleh panel surya pelacak matahari mengalami kenaikan ratarata sebesar 0.51 Ampere dibandingkan dengan nilai arus yang dihasilkan panel surya tetap.

Dari pengukuran tegangan dan arus dapat diperoleh nilai daya listrik. Daya listrik diperoleh dengan rumus perkalian antara nilai arus dan tegangan. Hasil pengukuran daya panel surya disajikan pada Tabel 3 . Perbandingan nilai daya listrik antara kedua sistem panel surya ditunjukkan pada Gambar 11 (c). Grafik pada Gambar 11 (c) menunjukkan bahwa terjadi kenaikan daya listrik pada panel surya berbasis sistem pelacak matahari rata-rata sebesar 10.299 Watt dibandingkan dengan panel surya yang dipasang tetap. Terjadi drop nilai daya listrik pada kedua panel surya pada pukul 08.16 yang dikarenakan karena faktor gangguan sambungan kabel sesaat pada sensor tegangan.

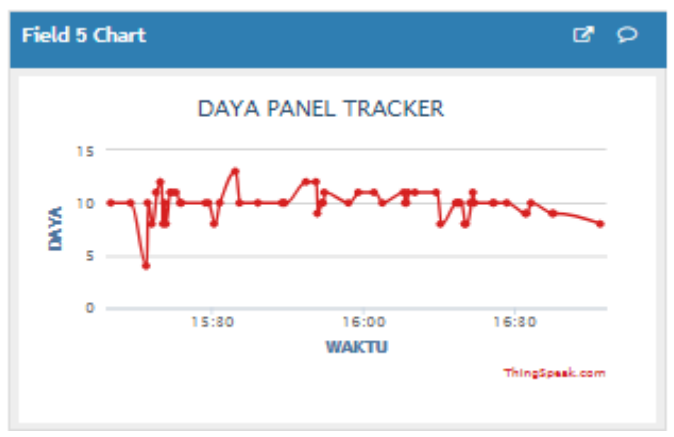

(A)

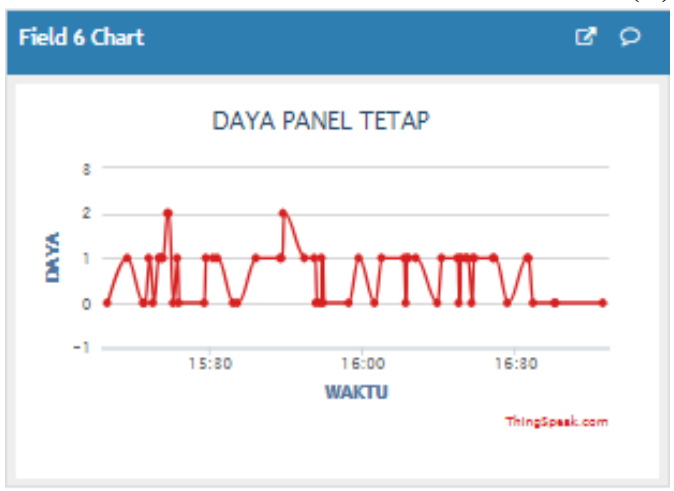

(B)
Gambar 12. Hasil Pengukuran Panel Surya menggunakan Thingspeak (a) Panel Surya

Pelacak dan (b) Panel Surya Tetap.
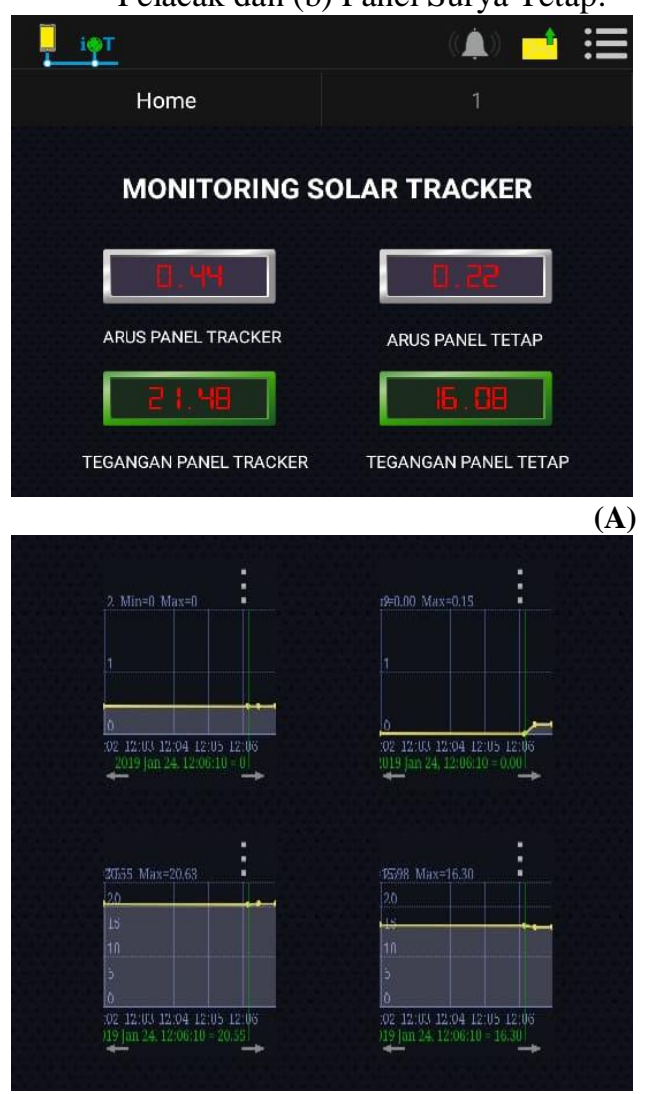

(B)

Gambar 13. Hasil Pengukuran Panel Surya menggunakan Virtuino (a) Tampilan besar nilai arus dan tegangan, dan (b) Tampilan grafik nilai arus dan tegangan.

Hasil monitoring tegangan dan arus pada kedua panel surya dapat dilihat melalui website thingspeak.com dan aplikasi android virtuino. Pada thingspeak perlu login dahulu dengan akun thingspeak yang dimiliki oleh pengguna. Thingspeak ini merupakan platform open source Internet of Things (IOT) aplikasi dan API untuk menyimpan dan mengambil data dari hal menggunakan protokol HTTP melalui Internet atau melalui Local Area Network. Apabila pengguna belum memiliki akun, maka dapat mendaftar terlebih dahulu dengan mengisi kolom registrasi yang diberikan. Pada opsi API Key akan ada key yang digunakan pada program di Arduino. Key tersebut berfungsi sebagai akses bagi program Arduino agar bisa terunggah ke server Thingspeak. Tampilan display dapat dilihat pada Gambar 12 dan 13. Pada kedua fitur ini akan mengupdate data setiap satu menit dan dapat diunduh ke dalam 
penyimpanan komputer atau gadget dalam format excel.

\section{KESIMPULAN}

Berdasarkan penelitian yang telah dilakukan panel surya sistem pelacak matahari otomatis berbasis komunikasi internet memiliki hasil data yang diperoleh panel surya berbasis sistem pelacak matahari yaitu tegangan, arus dan daya yang lebih besar dibandingkan dengan panel surya tetap dimana pada sistem pelacak otomatis nilai rata-rata sesaat arus 0.538 Ampere, tegangan 19.902 Volt, dan daya 10.707 Watt sedangkan pada panel surya tetap nilai rata-rata sesaat arus 0.028 Ampere, tegangan 14.599 Volt, dan daya 0.408 Watt.

\section{UCAPAN TERIMA KASIH}

Dalam penulisan karya tulis ini penulis mengucapkan terima kasih kepada pihakpihak yang terlibat membantu dan mendukung pada penyusunan karya tulis ini, antara lain:

1. Bapak Slamet Suyitno Raharjo, S. Si M. $\mathrm{Si}$ selaku Ketua Sekolah Tinggi Meteorologi Klimatologi dan Geofisika.

2. Bapak Drs. Agus Tri Sutanto, MT selaku dosen pembimbing.

3. Rekan-rekan kelas Instrumentasi 5B angkatan tahun 2016.

4. Semua pihak yang telah membantu menyelesaikan karya tulis ini.

\section{DAFTAR PUSTAKA}

Maulidya, Ririn., 2018, Analisis Perbandingan Efisiensi Panel Surya Berbasis Sistem Pelacak Matahari dengan Panel Surya Tetap, Skripsi, Program Sarjana Terapan Instrumentasi, Sekolah Tinggi Meteorologi Klimatologi dan Geofisika, Tangerang Selatan.

Midriem Mirdanies, Rizqi Andry A, Hendri Maja Saputra, Aditya Sukma Nugraha, Estiko Rijanto, Adi Santoso., 2011, Rancang Bangun Sistem Kontrol Mekanisme Pelacakan Matahari Beserta Fasilitas Telekontrol Hemat Energi, Pusat Penelitian Tenaga Listrik dan Mekatronik - LIPI Komp, Bandung.
M, Syamsuddin., 2014, Membuat Sendiri Pembangkit Listrik Tenaga Surya, Bukudigital.net dan Google Book Publisher.

Akibat Gerak Semu Matahari, 2018, https://ilmugeografi.com/ilmubumi/meteorologi/akibat-gerak-semumatahari, diakses 19 Februari 2019.

Sigit Nurharsanto, Adhy Prayitno., 2017, Sun Tracking Otomatis Untuk Pembangkit Listrik Tenaga Surya, Universitas Riau.

Saldi Eko Dwi Saputro, Yandri, Kho Hie Khwee., 2017, Analisis Perencanaan Pembangkit Listrik Tenaga Surya Berbantuan Program System Sizing Estimator, Universitas Tanjungpura.

Noer Soedjarwanto dan Osea Zebua., 2015, Sistem Pelacak Otomatis Energi Surya Berbasis Mikrokontroler ATMega8535, Universitas Lampung.

Mengenal Fritzing dan Express PCB, 2016, https://sunupradana.info/pe/2016/10/1 5/mengenal-fritzing-dan-expresspcb/, diakses 15 Maret 2019.

Andriani Parastiwi, Ratna Ika Putri, Supriatna Adhisuwignjo, dan Muhamad Rifa'i., 2018, Photovoltaic Terapan Teknologi dan Implementasi, UPT Percetakan dan Penerbitan Polinema.

Mengenal Platform IoT, 2017, http://sh4retech.blogspot.com/2017/03 /mengenal-platform-iot.html, diakses 19 Februari 2019. 